\title{
Temporarily decreasing progesterone after timed artificial insemination decreased expression of interferon-tau stimulated gene 15 (ISG15) in blood leukocytes, serum pregnancy-specific protein B concentrations, and embryo size in lactating Holstein cows
}

\author{
P. D. Carvalho, C. C. Consentini, S. R. Weaver, R. V. Barleta, L. L. Hernandez, and P. M. Fricke ${ }^{1}$ \\ Department of Dairy Science, University of Wisconsin, Madison 53706
}

\begin{abstract}
Our objective was to evaluate the effects of temporarily decreasing progesterone (P4) after timed artificial insemination (TAI) on embryonic growth in dairy cows. Lactating Holstein cows $(\mathrm{n}=80)$ were submitted to a Double-Ovsynch protocol for first TAI and were assigned randomly to receive $12.5 \mathrm{mg}$ of $\mathrm{PGF}_{2 \alpha} 5 \mathrm{~d}$ after the last $\mathrm{GnRH}$ treatment (LowP4) or remain untreated (control). Blood samples were collected thrice weekly from 5 to $29 \mathrm{~d}$ after TAI for all cows and from 32 to $67 \mathrm{~d}$ for pregnant cows, and were analyzed for P4 and pregnancy-specific protein B concentrations. Expression of interferon-tau stimulated gene 15 (ISG15) was assessed in blood leukocyte mRNA 18 and $20 \mathrm{~d}$ after TAI. Pregnancy diagnosis was performed weekly using ultrasound from 32 to $67 \mathrm{~d}$ after TAI, and embryonic crown-rump length was measured 32, 39, and $46 \mathrm{~d}$ after TAI. Data were analyzed by ANOVA and logistic regression using the MIXED and GLIMMIX procedures of SAS. The LowP4 cows had less $\mathrm{P} 4$ than control cows from 6 to $11 \mathrm{~d}$ after TAI; however, pregnancy outcomes $32 \mathrm{~d}$ after TAI and pregnancy loss from 32 to $67 \mathrm{~d}$ after TAI did not differ between treatments. Control cows diagnosed pregnant $32 \mathrm{~d}$ after TAI had greater expression of ISG15 $20 \mathrm{~d}$ after TAI than LowP4 cows diagnosed pregnant $32 \mathrm{~d}$ after TAI, and pregnant control cows had greater pregnancy-specific protein B concentrations from 25 to $67 \mathrm{~d}$ after TAI than pregnant LowP4 cows. Embryo size did not differ between treatments 32 and $39 \mathrm{~d}$ after TAI, but control cows had larger embryos $46 \mathrm{~d}$ after TAI. In conclusion, temporarily decreasing P4 after TAI decreased embryonic growth during early pregnancy in lactating Holstein cows but did not affect pregnancies per artificial insemination or pregnancy loss.
\end{abstract}

Received September 13, 2016.

Accepted December 15, 2016.

${ }^{1}$ Corresponding author: pmfricke@wisc.edu
Key words: progesterone, interferon-tau stimulated gene 15 , pregnancy-specific protein $\mathrm{B}$, embryo size

\section{INTRODUCTION}

A key hormone involved in control of the uterine environment is progesterone (P4; Ashworth and Bazer, 1989; Forde et al., 2009, 2012). Progesterone after AI is unequivocally required to support embryo development as well as for establishment and maintenance of pregnancy (reviewed by Spencer et al., 2016). Lactating Holstein cows have lower circulating P4 concentrations than nonlactating Holstein heifers (Sartori et al., 2004), and decreased $\mathrm{P} 4$ concentrations in lactating cows have been attributed to increased hepatic steroid metabolism associated with high feed intake (Sangsritavong et al., 2002; Vasconcelos et al., 2003; Wiltbank et al., 2006). In this regard, supplementation with exogenous P4 increases circulating P4 concentrations and induces changes in the endometrial transcriptome (Forde et al., 2009; Carter et al., 2010), leading to increased embryo elongation on d 13 to 16 of pregnancy (Carter et al., 2008; Clemente et al., 2009). By contrast, decreasing $\mathrm{P} 4$ concentrations decreased the abundance of mRNA for genes related to embryo elongation (Forde et al., 2011, 2012).

Based on these data, supplementation of cows with exogenous $\mathrm{P} 4$ after AI may increase fertility as measured by pregnancies per AI (P/AI). In vivo studies evaluating the effects of $\mathrm{P} 4$ supplementation after $\mathrm{AI}$ on $\mathrm{P} / \mathrm{AI}$ or pregnancies per embryo transfer, however, do not consistently support this idea. Results from various studies have reported an increase (Monteiro et al., 2014), no change (Stevenson et al., 2007; Monteiro et al., 2015), or a decrease (Parr et al., 2014) in P/AI for cows supplemented with exogenous $\mathrm{P} 4$ after ovulation compared with untreated controls. Although several studies evaluated the effect of decreasing P4 concentrations after ovulation on the uterine environment and embryo development (Forde et al., 2011, 2012), to our 
knowledge, only one study has evaluated the effect of decreasing P4 after ovulation on establishment of pregnancy (Kenyon et al., 2013). In that study, however, no pregnancies occurred after transfer of embryos into the uterus of cows manipulated to have low P4 concentrations.

Treatment with $12.5 \mathrm{mg}$ of $\mathrm{PGF}_{2 \alpha} 5 \mathrm{~d}$ after induction of ovulation induced a temporary decrease in $\mathrm{P} 4$ concentrations in lactating dairy cows without inducing complete luteal regression, which was followed by a rebound in circulating $\mathrm{P} 4$ concentrations (Carvalho et al., 2015). Our objective was to evaluate the effects of administration of $12.5 \mathrm{mg}$ of $\mathrm{PGF}_{2 \alpha}$ (dinoprost tromethamine) $5 \mathrm{~d}$ after induction of the $\mathrm{LH}$ surge on subsequent P4 concentrations and on experimental endpoints related to embryonic growth and development. These endpoints included interferon-stimulated gene 15 (ISG15) mRNA expression 18 and $20 \mathrm{~d}$ after TAI, serum pregnancy-specific protein B (PSPB) concentrations from 18 to $67 \mathrm{~d}$ after TAI, and embryonic crown-rump length at 32,39 , and $46 \mathrm{~d}$ after TAI. The rationale for our experimental approach was based on results from an experiment in which we reported a negative relationship between milk production and concentrations of pregnancy-associated glycoproteins (PAG) in both serum and milk (Ricci et al., 2015). We speculated that cows with greater milk production may have decreased $\mathrm{P} 4$ concentrations during embryo development because of increased hepatic metabolism of circulating P4 (Sangsritavong et al., 2002), which may in turn inhibit growth of the embryo, thereby resulting in decreased PAG production by the conceptus (Ricci et al., 2015). Our hypotheses were that cows treated with $12.5 \mathrm{mg}$ of $\mathrm{PGF}_{2 \alpha}$ would have (1) temporarily decreased $\mathrm{P} 4$ concentrations, (2) decreased expression of ISG15 mRNA, (3) decreased serum PSPB concentrations, and (4) smaller embryos than control cows.

\section{MATERIALS AND METHODS}

All animal handling and experimental procedures were approved by the Animal Care and Use Committee of the College of Agriculture and Life Sciences at the University of Wisconsin-Madison.

\section{Cows, Housing, and Feeding}

This study was conducted at the University of Wisconsin-Madison Emmons Blaine Dairy Cattle Research Center located near Arlington, Wisconsin, from September to December 2015. Lactating Holstein cows (n $=80$ ) were milked twice daily at approximately 12 -h intervals and were fed a TMR once daily consisting of corn and alfalfa silage as forage with corn and soybean meal-based concentrate formulated to meet or exceed the minimum nutritional requirements for highproducing dairy cows (NRC, 2001). Cows were housed in free-stall barns bedded with sand and had ad libitum access to feed and water. Primiparous cows were housed in separate pens from multiparous cows. The rolling herd average was $13,880 \mathrm{~kg}$ and average daily milk production was $41.6 \mathrm{~kg} /$ cow per d with $3.8 \%$ fat and $3.2 \%$ protein for the herd during the time period of this experiment.

\section{Experimental Treatments}

All cows were submitted to a Double-Ovsynch protocol for first TAI as described by Souza et al. (2008) and later modified by Brusveen et al. (2009) starting at $53 \pm 3$ DIM. The GnRH $(100 \mu \mathrm{g} /$ dose of gonadorelin hydrochloride, Factrel) and $\mathrm{PGF}_{2 \alpha}(25 \mathrm{mg} /$ dose of dinoprost tromethamine, Lutalyse) were manufactured by Zoetis (Madison, NJ). Briefly, cows received the first GnRH treatment of the Pre-Ovsynch portion of the Double-Ovsynch protocol, followed by a treatment with $\mathrm{PGF}_{2 \alpha} 7 \mathrm{~d}$ later and treatment with GnRH $72 \mathrm{~h}$ after administration of $\mathrm{PGF}_{2 \alpha}$. Seven days later, cows began the Breeding-Ovsynch portion of the Double Ovsynch protocol in which cows received a $\mathrm{GnRH}$ treatment, followed by $2 \mathrm{PGF}_{2 \alpha}$ treatments administered 7 and 8 d later and the last GnRH treatment (G2) administered $56 \mathrm{~h}$ after the first $\mathrm{PGF}_{2 \alpha}$ treatment followed by TAI 16 to $20 \mathrm{~h}$ after G2. Primiparous $(\mathrm{n}=11)$ and multiparous $(\mathrm{n}=69)$ cows were blocked by parity (primiparous vs. multiparous) and were assigned randomly to receive no treatment (control) or to receive $12.5 \mathrm{mg}$ of $\mathrm{PGF}_{2 \alpha}$ (LowP4; dinoprost tromethamine) $5 \mathrm{~d}$ after G2 (Figure 1). Multiple sires with high genetic merit and proven fertility were used for TAI, and sires were equally balanced between treatments.

\section{Ultrasound Evaluation of Ovaries}

Location and number of corpora lutea were evaluated weekly beginning $5 \mathrm{~d}$ after TAI until cows were diagnosed not pregnant or until $67 \mathrm{~d}$ after TAI for pregnant cows (Figure 1) by transrectal ultrasonography using a portable scanner (Ibex Pro, E. I. Medical Imaging, Loveland, CO) equipped with a $7.5-\mathrm{MHz}$ linear-array transducer. Two cows lacking a corpus luteum $5 \mathrm{~d}$ after TAI (one control cow and one LowP4 cow) failed to synchronize in response to the Double-Ovsynch protocol and were removed from the experiment, resulting in 39 cows in each treatment. 


\section{Blood Sampling}

Blood samples for P4 and PSPB were collected via puncture of the median caudal veins or arteries into 8-mL evacuated serum collection tubes (Vacuette, Greiner Bio-One North America Inc., Monroe, NC) thrice weekly beginning $5 \mathrm{~d}$ after G2 (i.e., immediately before treatment) until $32 \mathrm{~d}$ after TAI for all cows and then weekly until $67 \mathrm{~d}$ for cows diagnosed pregnant 32 $\mathrm{d}$ after TAI (Figure 1). Blood samples were refrigerated immediately after collection for $24 \mathrm{~h}$ and centrifuged $\left(1,600 \times g ; 4^{\circ} \mathrm{C}\right)$ for $20 \mathrm{~min}$. Serum was harvested and stored at $-20^{\circ} \mathrm{C}$ until assayed for $\mathrm{P} 4$ and PSPB. Blood samples $(3 \mathrm{~mL})$ for analysis of ISG15 mRNA expression were collected 4, 18, and $20 \mathrm{~d}$ after TAI from the coccygeal vessels into Tempus Blood RNA tubes containing 6 $\mathrm{mL}$ of RNA stabilization solution (Applied Biosystems, Foster City, CA). Tubes were shaken by hand vigorously for $20 \mathrm{~s}$ immediately after collection, and whole blood was stored at $-20^{\circ} \mathrm{C}$ until analysis.

\section{Analysis of Progesterone and Pregnancy- Specific Protein B}

Progesterone concentrations were determined using a solid-phase, no-extraction RIA (MP Biomedicals, Solon, $\mathrm{OH}$ ). The average sensitivity for the 3 assays was $0.027 \mathrm{ng} / \mathrm{mL}$. The average intraassay $\mathrm{CV}$ was $5.6 \%$, and the interassay $\mathrm{CV}$ was $6.9 \%$ based on a quality control sample $(2.50 \mathrm{ng} / \mathrm{mL}$ of $\mathrm{P} 4)$, which was replicated within each assay. Concentrations of PSPB were determined using a quantitative ELISA (Biopryn, BioTracking LLC, Moscow, ID). The average intraassay CV was $5.3 \%$, and the interassay CV was $7.4 \%$ based on a quality control sample (0.9 ng/mL of PSPB), which was replicated within each assay.

\section{Analysis of ISG15}

Total RNA was extracted from blood leukocytes using the Tempus Spin RNA Isolation Kit (Applied Biosystems, Foster City, CA) as per the manufacturer's instructions including the optional DNase step. Extracted RNA $(1 \mu \mathrm{g})$ was reverse transcribed to cDNA (Bio-Rad iScript Reverse Transcription Supermix \#1708840). Quantitative real-time PCR was conducted with the CFX96 Touch Real-Time PCR Detection System (BioRad). Reaction mixtures and cycling conditions were performed as described elsewhere (Laporta et al., 2013). Amplification efficiencies of primers were accepted within a range of 95 to $105 \%$ efficiency and primer specificity was assessed by the presence of a single temperature dissociation peak. Cyclophilin A (CycloA; NM_178320; forward 5'-CACCGTGTTCTTCGACATCG-3', reverse 5'-ACAGCTCAAAAGAGACGCGG-3') was used as a housekeeping gene, and all samples were analyzed for ISG15 (NM_174366; forward 5'-GGTATGAGCTGAAGCAGTT-3', reverse 5'-ACCTCCCTGCTGTCAAGGT- $\left.3^{\prime}\right)$. Analysis was conducted using the $2^{-\Delta \Delta \mathrm{Ct}}$ method (Livak and Schmittgen, 2001). Blood samples collected $4 \mathrm{~d}$ after TAI served as a reference to calculate fold-change in ISG15 mRNA expression 18 and $20 \mathrm{~d}$ after TAI.

\section{Pregnancy Diagnosis and Evaluation of Embryonic Crown-Rump Length}

Pregnancy diagnosis and measurement of embryonic crown-rump length was performed using a portable scanner (Ibex Pro, E. I. Medical Imaging, Loveland, $\mathrm{CO}$ ) equipped with a $7.5-\mathrm{MHz}$ linear-array transducer. A positive pregnancy diagnosis was based on visualization of a corpus luteum on the ovary ipsilateral to the

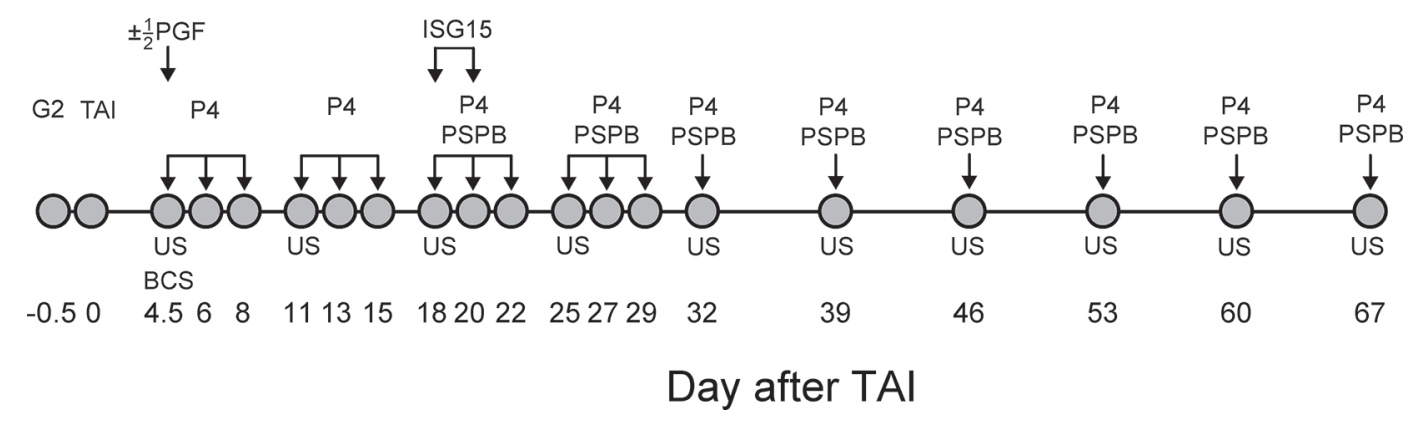

Figure 1. Schematic representation of treatments and data collection. Cows were submitted to a Double-Ovsynch protocol for synchronization of ovulation for first timed artificial insemination (TAI). The first GnRH treatment of the Pre-Ovsynch portion of the Double-Ovsynch protocol was followed by treatment with $\mathrm{PGF}_{2 \alpha} 7 \mathrm{~d}$ later and $\mathrm{GnRH} 72 \mathrm{~h}$ after $\mathrm{PGF}_{2 \alpha}$. Seven days later, cows were treated with GnRH followed by $2 \mathrm{PGF}_{2 \alpha}$ treatments administered 7 and $8 \mathrm{~d}$ later with the last GnRH (G2) treatment administered $56 \mathrm{~h}$ after the first PGF $2 \alpha$ treatment and TAI 16 to $20 \mathrm{~h}$ later. Five days after the last GnRH treatment, cows were assigned randomly to receive $12.5 \mathrm{mg}$ of dinoprost tromethamine (LowP4) or remain untreated (control). P4 = progesterone; ISG15 = interferon stimulated gene 15; PSPB = pregnancy-specific protein B; US $=$ transrectal ultrasonography. 
uterine horn containing an embryo with a heartbeat. Pregnancy status for cows diagnosed pregnant $32 \mathrm{~d}$ after TAI was reconfirmed weekly until $67 \mathrm{~d}$ after TAI. Any cow diagnosed pregnant and then diagnosed not pregnant at a subsequent pregnancy examination was considered to have undergone pregnancy loss. Embryonic crown-rump length was measured 32,39 , and 46 $\mathrm{d}$ after TAI. Images were frozen when the crown-rump length was determined visually to be at its maximal size, and was then measured using the built-in digital calipers of the ultrasound machine.

\section{Statistical Analyses}

The experiment was conducted as a completely randomized design. Cows were stratified by parity (primiparous vs. multiparous) and were then randomly assigned to treatments to balance parity between treatments. All statistical analyses were performed using SAS computational software, version 9.3 for Microsoft Windows (SAS Institute Inc., Cary, NC). Analyses of binary response data (P/AI and pregnancy loss) were performed by logistic regression using the GLIMMIX procedure of SAS. The model included the fixed effects of parity and treatment. Concentrations of P4 (from 4 to $15 \mathrm{~d}$, and from 18 to $67 \mathrm{~d}$ after TAI) and PSPB were analyzed by ANOVA using the MIXED procedure of SAS. The model contained the fixed effects of parity, treatment, time, pregnancy status, and all 2 -way interactions. Due to repeated measures within each cow, a repeated statement was used to account for autocorrelations by modeling the spatial power between sequential measurements. Fold-change in ISG15 mRNA from 4 to 18 and $20 \mathrm{~d}$ after TAI was analyzed by ANOVA using the MIXED procedure of SAS. The model contained the fixed effects of parity, treatment, pregnancy status $32 \mathrm{~d}$ after TAI (pregnant vs. open), and all 2-way interactions. A significant difference between levels of a classification variable was considered when $P \leq 0.05$, whereas differences between $P>0.05$ and $P \leq 0.10$ were considered a statistical tendency. Data are presented as least squares means \pm standard error of the mean obtained from the MIXED procedure of SAS.

\section{RESULTS AND DISCUSSION}

Several experiments have focused on the effect of increasing P4 early after ovulation on uterine physiology and early embryonic growth. Supplementation with exogenous $\mathrm{P} 4$ increases circulating $\mathrm{P} 4$ concentrations and induces changes in the endometrial transcriptome (Forde et al., 2009, 2011; Carter et al., 2010), result- ing in a dramatic increase in embryo elongation on $\mathrm{d}$ 13 to 16 of pregnancy (Carter et al., 2008; Clemente et al., 2009). Progesterone exerts these effects on the embryo and conceptus indirectly by altering the uterine environment and thereby accelerating conceptus development (Clemente et al., 2009). Based on these data, supplementation with exogenous P4 after AI has been thought to be a practical strategy to increase fertility in dairy cows. Results from large field trials are equivocal, however, reporting an increase (Monteiro et al., 2014), no change (Stevenson et al., 2007; Monteiro et al., 2015), or a decrease (Parr et al., 2014) in P/AI for dairy cows treated with exogenous $\mathrm{P} 4$ early after ovulation compared with untreated controls.

In the present study, we took an alternative approach to assessing the effect of $\mathrm{P} 4$ after AI by temporarily decreasing $\mathrm{P} 4$ concentrations early after ovulation. Thus, our overall hypothesis was that decreasing P4 early after ovulation would decrease embryonic growth. Our experimental endpoints included various proxies for embryonic growth including ISG15 mRNA expression 18 and $20 \mathrm{~d}$ after TAI, serum PSPB concentrations 18 to $67 \mathrm{~d}$ after TAI, and embryonic crown-rump length 32,39 , and $46 \mathrm{~d}$ after TAI.

\section{Effect of Treatment on Serum Progesterone Concentrations}

The early bovine corpus luteum does not undergo complete luteal regression in response to a single $\mathrm{PGF}_{2 \alpha}$ treatment (Rowson et al., 1972; Henricks et al., 1974; Momont and Seguin, 1984), and several studies have reported a transient decrease in circulating $\mathrm{P} 4$ before functional recovery of the corpus luteum (Nascimento et al., 2014; Carvalho et al., 2015). In the present experiment, we administered $12.5 \mathrm{mg}$ of $\mathrm{PGF}_{2 \alpha} 5 \mathrm{~d}$ after the last GnRH treatment of a Double-Ovsynch protocol to temporarily decrease P4 after TAI. Five days after G2 (i.e., immediately before administration of treatment), P4 concentrations did not differ $(P=$ 0.15 ) between treatments (Figure 2). From 6 to $11 \mathrm{~d}$ after TAI, LowP4 cows had less $(P<0.01)$ serum P4 than control cows (Figure 2). After this transient decrease, serum P4 concentrations did not differ between treatments $13(P=0.20)$ or $15(P=0.57) \mathrm{d}$ after TAI (Figure 2). Overall, $\mathrm{P} 4$ concentrations did not differ $(P$ $=0.11)$ between parities $(4.3 \pm 0.3$ vs. $3.9 \pm 0.1 \mathrm{ng} /$ $\mathrm{mL}$ for primiparous vs. multiparous cows) from 4 to 15 d after TAI.

The resulting $\mathrm{P} 4$ profile after administration of 12.5 mg of $\mathrm{PGF}_{2 \alpha}$ in the present study (Figure 2) adds to the body of literature demonstrating that the early corpus luteum does not fully regress in response to 


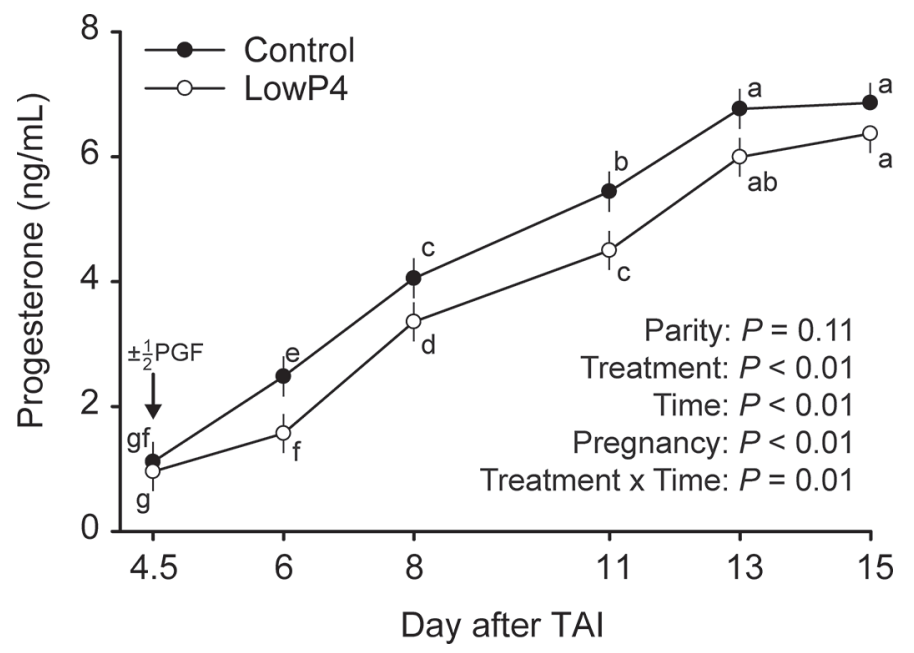

Figure 2. Mean $( \pm \mathrm{SEM})$ progesterone concentration from 4.5 to $15 \mathrm{~d}$ after timed artificial insemination (TAI). Cows were submitted to a Double-Ovsynch protocol for synchronization of ovulation for first TAI. Five days after the last GnRH treatment, cows were assigned randomly to receive $12.5 \mathrm{mg}$ of dinoprost tromethamine (LowP4; open circles) or remain untreated (control; closed circles). Different letters $(\mathrm{a}-\mathrm{g})$ denote differences $(P<0.05)$ across time within treatment as well as between treatments.

exogenous $\mathrm{PGF}_{2 \alpha}$ (Nascimento et al., 2014). Rather, P4 transiently decreases followed by recovery of luteal function particularly when a reduced dose of $\mathrm{PGF}_{2 \alpha}$ is administered (Carvalho et al., 2015). The lack of regression of the early corpus luteum is an intriguing biological phenomenon arising from the inability of a single bolus of exogenous $\mathrm{PGF}_{2 \alpha}$ to completely activate intracellular signal transduction pathways in the early corpus luteum (Tsai and Wiltbank, 1998; Mondal et al., 2011; Diaz et al., 2013). In agreement with other studies (Mann and Lamming, 2001; Gümen et al., 2003; Sterry et al., 2009), cows diagnosed pregnant $32 \mathrm{~d}$ after TAI in the present study had greater mean P4 concentrations from 4 to $15 \mathrm{~d}$ after TAI than cows diagnosed not pregnant $(4.6 \pm 0.2$ vs. $3.7 \pm 0.2 \mathrm{ng} / \mathrm{mL}$, respectively).

From 15 d after TAI onward, P4 concentrations did not differ $(P=0.82)$ between treatments $(6.6 \pm 0.2$ vs. $6.7 \pm 0.2 \mathrm{ng} / \mathrm{mL}$, for control vs. LowP 4 cows) or $(P=0.82)$ parities $(7.3 \pm 0.4$ vs. $6.6 \pm 0.2 \mathrm{ng} / \mathrm{mL}$, for primiparous vs. multiparous cows). Overall $\mathrm{P} 4$ concentrations for cows that became pregnant remained high from 18 to $67 \mathrm{~d}$ after TAI, whereas P4 concentrations for nonpregnant cows began to decrease $18 \mathrm{~d}$ after TAI (Figure 3). Cows identified not pregnant $32 \mathrm{~d}$ after TAI in the present study were resynchronized for second TAI and blood sampling was discontinued. No treatment by pregnancy status interaction $(P=0.87)$ was present for $\mathrm{P} 4$ from 18 to $67 \mathrm{~d}$ after TAI.

\section{Effect of Treatment on ISG15 mRNA Expression}

Interferon-tau is a member of the type I IFN family (Roberts et al., 1997) and is an early signal for maternal recognition of pregnancy in ruminants (Spencer and Bazer, 2004). Interferon-tau is secreted by the mononuclear trophectoderm cells of the ruminant conceptus (reviewed by Spencer et al., 2007, and Bazer et al., 2012), which in turn induces expression of a large number of IFN-stimulated genes in the uterine endometrium (Gray et al., 2006) and in circulating blood leukocytes (Gifford et al., 2007; Green et al., 2010). Several IFN-stimulated genes have been used to determine pregnancy status in dairy cows including ISG15 (Han et al., 2006; Gifford et al., 2007).

In the present experiment, we assessed the effect of both treatment and pregnancy status on fold-change in ISG15 mRNA expression from 4 to 18 and $20 \mathrm{~d}$ after TAI. At $18 \mathrm{~d}$ after TAI, pregnant cows had a 4-fold increase $(P<0.01)$ in ISG15 relative mRNA expression compared with $4 \mathrm{~d}$ after TAI than nonpregnant cows (Figure 4); however, relative mRNA expression did not differ between treatments $(P=0.78)$ or parities $(P=$ 0.21 ), and no treatment by pregnancy status interaction $(P=0.64)$ was present. At $20 \mathrm{~d}$ after TAI, pregnant cows had a 6 -fold increase $(P<0.01)$ in ISG15 mRNA expression relative to $4 \mathrm{~d}$ after TAI compared with nonpregnant cows (Figure 4). Relative ISG15 mRNA expression did not differ $(P=0.64)$ between treatments for nonpregnant cows $20 \mathrm{~d}$ after TAI; however, pregnant control cows had 3 -fold greater $(P=0.04)$ relative ISG15 mRNA expression relative to $4 \mathrm{~d}$ after TAI than pregnant LowP4 cows (Figure 4).

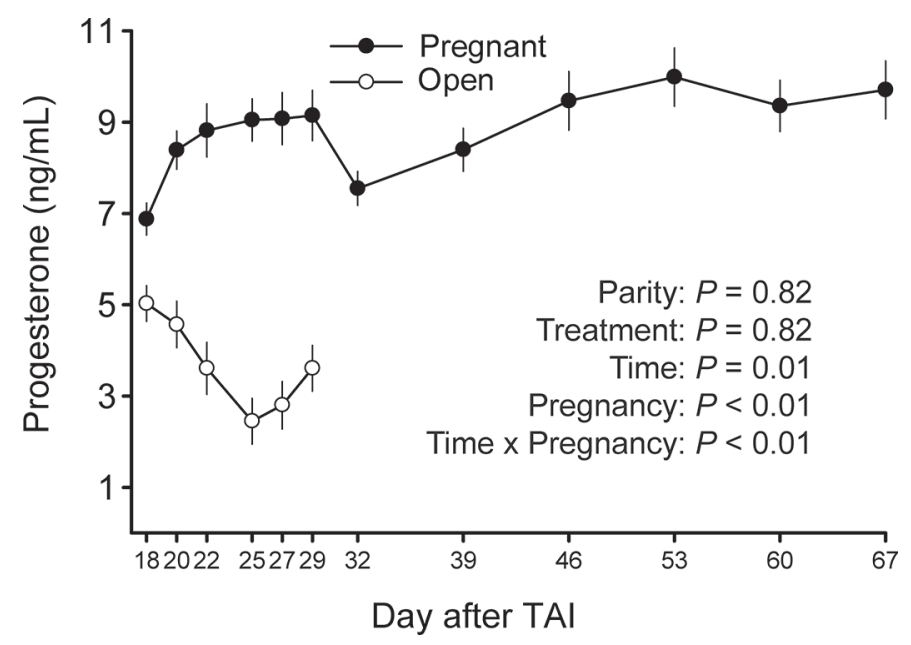

Figure 3. Mean $( \pm \mathrm{SEM})$ progesterone concentration from 18 to 67 d after timed artificial insemination (TAI) for cows diagnosed pregnant (closed circles) or not pregnant (open circles) $32 \mathrm{~d}$ after TAI. 


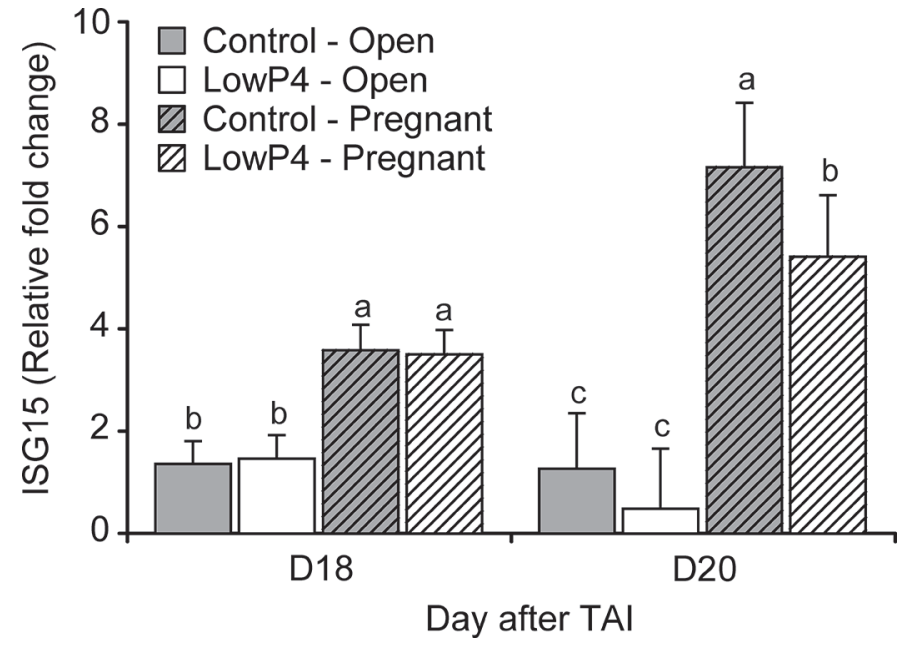

Figure 4. Mean $( \pm \mathrm{SEM})$ relative fold-change in interferon-stimulated gene 15 (ISG15) from 4 to 18 and $20 \mathrm{~d}$ after timed artificial insemination (TAI). Cows were submitted to a Double-Ovsynch protocol for synchronization of ovulation for first TAI. Five days after the last GnRH treatment, cows were assigned randomly to receive $12.5 \mathrm{mg}$ of dinoprost tromethamine (LowP4; open bars) or remain untreated (control; shaded bars). Different letters $(\mathrm{a}-\mathrm{c})$ within a day denote differences $(P<0.05)$ between treatment and pregnancy status.

Concentrations of IFN-tau in uterine flushings have been correlated with trophoblast length (Mann et al., 2006) and the amount of mRNA for IFN-stimulated genes isolated from peripheral blood leukocytes (Matsuyama et al., 2012). Therefore, increased ISG15 mRNA expression $16 \mathrm{~d}$ after AI in cows with high circulating P4 after AI (Forde et al., 2009), and decreased ISG15 mRNA expression $20 \mathrm{~d}$ after TAI in cows with low P4 in the present study (Figure 4), support the idea that decreasing circulating P4 concentrations early after ovulation decreased embryonic growth. These data are interesting in light of another study conducted in Irish Holstein-Friesian cows in which cows manipulated to have low circulating P4 during growth of the preovulatory follicle before TAI had increased levels of ISG15 mRNA expression in blood leukocytes $18 \mathrm{~d}$ after TAI compared with cows manipulated to have high circulating P4 before TAI (Fricke et al., 2016). The day after TAI that ISG15 mRNA expression was assessed (i.e., 18 vs. 20) and the physiology of high-producing dairy cows used in the present experiment versus moderately producing Irish-Holstein Friesian cows managed in a pasture-based system may account for these differences in ISG15 mRNA expression.

\section{Effect of Treatment on Serum PSPB Concentrations}

In 1982, 2 proteins, pregnancy-specific proteins A and $\mathrm{B}$, were isolated from bovine fetal membrane extracts
(Butler et al., 1982). Development of a specific RIA for PSPB allowed for quantification of PSPB in maternal serum as an indirect method for pregnancy diagnosis (Sasser et al., 1986) and assessment of pregnancy loss (Giordano et al., 2012) in dairy cows. Molecular cloning and sequencing studies revealed that PAG belong to a large family of inactive aspartic proteinases expressed by the placenta of domestic ruminants including cows, ewes, and goats (Haugejorden et al., 2006). We (Ricci et al., 2015) and others (López-Gatius et al., 2007) have reported a negative relationship between milk production and concentrations of circulating PAG. We speculated that cows with greater milk production may have decreased P4 concentrations because of increased hepatic metabolism of circulating P4 (Sangsritavong et al., 2002), which may in turn inhibit growth of the embryo, resulting in decreased PAG production by the embryo (Ricci et al., 2015). This was our primary rationale for assessing the effect of temporarily decreasing P4 early after TAI on embryonic growth in the present experiment.

Overall, serum PSPB concentrations for cows diagnosed pregnant $32 \mathrm{~d}$ after TAI in the present experiment were low 18 and $20 \mathrm{~d}$ after TAI for cows in both treatments and then began to increase $22 \mathrm{~d}$ after TAI (Figure 5). Similar to serum PSPB (Sasser et al., 1986) and PAG profiles in serum and milk (Ricci et al., 2015) reported in other studies, overall serum PAG concentrations increased to an early peak $32 \mathrm{~d}$ after TAI, then transiently decreased from 32 to $46 \mathrm{~d}$ after TAI followed by an increase from 53 to $67 \mathrm{~d}$ after TAI. Control cows had greater $(P=0.04)$ serum PSPB concentrations than LowP4 cows from 25 to $67 \mathrm{~d}$ after TAI (Figure 5). No treatment by time interaction $(P$ $=0.29$ ) was present. In contrast to other studies that measured serum PAG (Ricci et al., 2015; Fricke et al., 2016) and milk PAG (Ricci et al., 2015) in lactating Holstein cows, concentrations of PSPB did not differ $(P=0.22)$ between parities $(1.5 \pm 0.1$ vs. $1.3 \pm 0.1 \mathrm{ng} /$ $\mathrm{mL}$, for primiparous vs. multiparous cows).

Data from PSPB concentrations in the present study further support the idea that temporarily decreasing P4 after TAI decreased embryonic growth. Whereas the effect of treatment on P4 after AI was temporary and restricted to early pregnancy (i.e., from 6 to $11 \mathrm{~d}$ after TAI; Figure 2), the effect of treatment on serum PSPB concentrations was manifested 25 to $67 \mathrm{~d}$ after TAI (Figure 5), suggesting a long-term effect of treatment on embryonic and fetal growth. Further, the pattern of decreased PSPB in Figure 5 is not only due to a delay in embryonic and fetal growth because PSPB levels for lowP4 cows never reached PSPB concentrations of control cows (i.e., the PSPB pattern over time 
for LowP4 cows was not simply shifted to the right). Data from Figure 5 indicate that although decreased P4 early after TAI decreased overall PSPB concentrations, factors other than embryonic size account for the temporal change in PSPB during early pregnancy (i.e., the transient dip in PSPB concentrations occurring from 32 to $67 \mathrm{~d}$ after TAI). This temporal pattern in PSPB and PAG concentrations has been consistently reported among studies and remains an intriguing biological phenomenon that is not completely understood.

\section{Effect of Treatment on Embryonic Crown-Rump Length}

Crown-rump length of embryos and fetuses recovered from dairy cows of known gestational age is highly correlated with stage of pregnancy (Rexroad et al., 1974), and transrectal ultrasonography is a noninvasive and highly accurate method for measuring embryonic crown-rump length in dairy cows (Hughes and Davies, 1989). In the present study, embryonic crown-rump length increased $(P<0.01)$ from 32 to $46 \mathrm{~d}$ after TAI for cows in both treatments (Table 1). At $32 \mathrm{~d}$ after TAI, embryonic crown-rump length did not differ $(P$ $=0.84$ ) between treatments (Table 1 ); however, primiparous cows had smaller $(P=0.02)$ embryos than multiparous cows $(10.1 \pm 1.3$ vs. $12.4 \pm 0.6 \mathrm{~mm}$, respectively). At $39 \mathrm{~d}$ after TAI, embryonic crown-rump length did not differ $(P=0.59)$ between treatments (Table 1$)$ or parities $(P=0.20 ; 14.5 \pm 1.3$ vs. 16.6

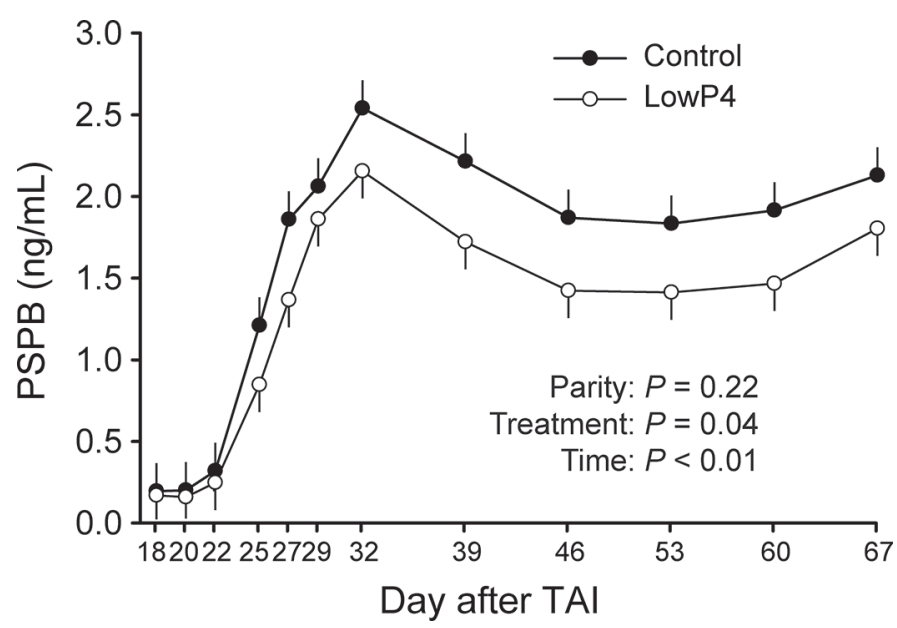

Figure 5. Mean $( \pm \mathrm{SEM})$ pregnancy-specific protein B (PSPB) concentrations for pregnant cows from 18 to $67 \mathrm{~d}$ after timed artificial insemination (TAI). Cows were submitted to a Double-Ovsynch protocol for synchronization of ovulation for first TAI. Five days after the last $\mathrm{GnRH}$ treatment, cows were assigned randomly to receive $12.5 \mathrm{mg}$ of dinoprost tromethamine (LowP4; open circles) or remain untreated (control; closed circles).
Table 1. Effect of treatment (mean \pm SEM) on embryonic crownrump length $(\mathrm{mm}) 32,39$, and $46 \mathrm{~d}$ after timed artificial insemination (TAI)

\begin{tabular}{lccc}
\hline & \multicolumn{2}{c}{ Treatment $^{1}$} & \\
\cline { 2 - 3 } $\begin{array}{l}\text { Days } \\
\text { after TAI }\end{array}$ & Control & LowP4 & $P$-value \\
\hline 32 & $10.8 \pm 1.0$ & $11.6 \pm 0.8$ & 0.84 \\
39 & $15.0 \pm 1.0$ & $16.1 \pm 0.8$ & 0.59 \\
46 & $26.3 \pm 1.0$ & $24.0 \pm 0.8$ & 0.02 \\
\hline
\end{tabular}

${ }^{1}$ Cows were submitted to a Double-Ovsynch protocol for synchronization of ovulation to receive first TAI. Five days after the last $\mathrm{GnRH}$ treatment, cows were assigned randomly to receive $12.5 \mathrm{mg}$ of dinoprost tromethamine (LowP4) or remain untreated (control).

$\pm 0.6 \mathrm{~mm}$ for primiparous vs. multiparous cows). In contrast, embryonic crown-rump length was greater $(P$ $=0.02$ ) for control than for LowP 4 cows $46 \mathrm{~d}$ after TAI, but did not differ $(P=0.62)$ between parities $(25.9 \pm$ 1.3 vs. $24.4 \pm 0.6 \mathrm{~mm}$ for primiparous vs. multiparous cows).

Data on crown-rump length $46 \mathrm{~d}$ after TAI in the present study directly supports that decreasing P4 early after TAI decreased embryonic growth. Similar to the effect of treatment on serum PSPB, the effect of treatment on embryonic crown-rump length was manifested long after the transient decrease in P4 after TAI occurred. Although we do not know why embryonic crown-rump length did not differ 32 or $39 \mathrm{~d}$ after TAI, we speculate that small differences in crown-rump length at these early stages of embryonic development may have exceeded the sensitivity of transrectal ultrasonography to detect them.

\section{Effect of Treatment on P/AI and Pregnancy Loss}

Overall, $\mathrm{P} / \mathrm{AI}$ did not differ between treatments, and $43.6 \%(17 / 39)$ of cows in each treatment were diagnosed pregnant $32 \mathrm{~d}$ after TAI (Table 2). At $32 \mathrm{~d}$ after TAI, $\mathrm{P} / \mathrm{AI}$ did not differ $(P=0.44)$ between parities $[54.5 \%(6 / 11)$ vs. $41.8 \%(28 / 67)$ for primiparous vs. multiparous cows]. Pregnancy loss between 32 and 67 $\mathrm{d}$ after TAI did not differ $(P=0.79)$ between treatments (Table 2$)$ or $(P=0.30)$ parities $[16.7 \%(1 / 6)$ vs. $3.6 \%(1 / 28)$ for primiparous vs. multiparous cows]. Although this experiment was not statistically powered to detect treatment effects on $\mathrm{P} / \mathrm{AI}$ or pregnancy loss, the proportion of pregnant cows in each treatment was identical 32, 39, 53, 60, and $67 \mathrm{~d}$ after TAI, and only one cow in each treatment underwent pregnancy loss from 32 to $67 \mathrm{~d}$ after TAI (Table 2). Thus, decreasing P4 early after TAI did not have a lethal effect on the embryo. Further, these proportions of primiparous and multiparous cows diagnosed pregnant $32 \mathrm{~d}$ after TAI are typical for cows submitted to TAI after the Double- 
Table 2. Effect of treatment on pregnancies per artificial insemination (P/AI) from 32 to $67 \mathrm{~d}$ after timed artificial insemination (TAI) and pregnancy loss from 32 to $67 \mathrm{~d}$ after TAI

\begin{tabular}{|c|c|c|c|}
\hline \multirow{2}{*}{$\begin{array}{l}\text { Item } \\
[\% \text { (no./no. })]\end{array}$} & \multicolumn{2}{|c|}{ Treatment $^{1}$} & \multirow[b]{2}{*}{$P$-value } \\
\hline & Control & LowP4 & \\
\hline \multicolumn{4}{|l|}{ Days after TAI } \\
\hline 32 & $43.6(17 / 39)$ & $43.6(17 / 39)$ & 0.98 \\
\hline 39 & $43.6(17 / 39)$ & $43.6(17 / 39)$ & 0.98 \\
\hline 46 & $41.0(16 / 39)$ & $43.6(17 / 39)$ & 0.84 \\
\hline 53 & $41.0(16 / 39)$ & $41.0(16 / 39)$ & 0.99 \\
\hline 60 & $41.0(16 / 39)$ & $41.0(16 / 39)$ & 0.99 \\
\hline 67 & $41.0(16 / 39)$ & $41.0(16 / 39)$ & 0.99 \\
\hline Pregnancy loss & $5.9(1 / 17)$ & $5.9(1 / 17)$ & 0.79 \\
\hline
\end{tabular}

${ }^{1}$ Cows were submitted to a Double-Ovsynch protocol for synchronization of ovulation to receive first TAI. Five days after the last GnRH treatment, cows were assigned randomly to receive $12.5 \mathrm{mg}$ of dinoprost tromethamine (LowP4) or remain untreated (control).

Ovsynch protocol used for synchronization of ovulation in the present experiment.

The present experiment showed no indication that decreasing $\mathrm{P} 4$ from 6 to $11 \mathrm{~d}$ after TAI had a major effect on fertility or pregnancy loss, bringing into question the idea that increasing P4 early after AI might be a practical strategy to increase fertility in lactating dairy cows. During the normal estrous cycle, downregulation of endometrial P4 receptors is followed by appearance of estrogen receptor $\alpha$ and oxytocin receptors leading to the pulsatile secretion of $\mathrm{PGF}_{2 \alpha}$, which induces luteolysis (McCracken et al., 1999). Progesterone downregulates its own receptor, and loss of endometrial $\mathrm{P} 4$ receptors seems to be required for secretion of histotroph (Spencer and Bazer, 2002) and implantation (Spencer and Bazer, 1995; Lessey et al., 1996; Kimmins and Maclaren, 2001). Interestingly, nuclear P4 receptor expression was greater in heifers with low $\mathrm{P} 4$ concentrations $7 \mathrm{~d}$ after ovulation than control heifers (Forde et al., 2012). In addition, supplementation with exogenous $\mathrm{P} 4$ from 4 to $18 \mathrm{~d}$ after AI increased the percentage of cows undergoing luteolysis by $19 \mathrm{~d}$ after AI (Monteiro et al., 2014). Thus, although increasing P4 concentrations after AI advanced embryo elongation, early downregulation of endometrial $\mathrm{P} 4$ receptors and advancement of the luteolytic cascade mechanism could explain why increasing $\mathrm{P} 4$ concentrations after AI has equivocal effects on P/AI among studies. In this regard, recent studies reported minimal or no benefit of increasing $\mathrm{P} 4$ concentrations after $\mathrm{AI}$ on $\mathrm{P} / \mathrm{AI}$ in dairy cows (Nascimento et al., 2013; Yan et al., 2016).

\section{ACKNOWLEDGMENTS}

We thank the University of Wisconsin-Madison dairy herd personnel at the Emmons Blaine Dairy Cattle
Research Center in Arlington, Wisconsin, for their assistance with data collection and cow handling during the course of this experiment. This work was supported by the USDA National Institute of Food and Agriculture (Washington, DC) Hatch project 231440 to P. M. Fricke.

\section{REFERENCES}

Ashworth, C. J., and F. W. Bazer. 1989. Changes in ovine conceptus and endometrial function following asynchronous embryo transfer or administration of progesterone. Biol. Reprod. 40:425-433.

Bazer, F. W., J. Kim, G. Song, H. Ka, C. D. Tekwe, and G. Wu. 2012. Select nutrients, progesterone, and interferon tau affect conceptus metabolism and development. Ann. N. Y. Acad. Sci. 1271:88-96.

Brusveen, D. J., A. H. Souza, and M. C. Wiltbank. 2009. Effects of additional prostaglandin F $2 \alpha$ and estradiol-17 $\beta$ during Ovsynch in lactating dairy cows. J. Dairy Sci. 92:1412-1422.

Butler, J. E., W. C. Hamilton, R. G. Sasser, C. A. Ruder, G. M. Haas, and R. J. Williams. 1982. Detection and partial characterization of two bovine pregnancy-specific proteins. Biol. Reprod. 26:925-933.

Carter, F., N. Forde, P. Duffy, M. Wade, T. Fair, M. A. Crowe, A. C. O. Evans, D. A. Kenny, J. F. Roche, and P. Lonergan. 2008. Effect of increasing progesterone concentration from Day 3 of pregnancy on subsequent embryo survival and development in beef heifers. Reprod. Fertil. Dev. 20:368-375.

Carter, F., F. Rings, S. Mamo, M. Holker, A. Kuzmany, U. Besenfelder, V. Havlicek, J. P. Mehta, D. Tesfaye, K. Schellander, and P. Lonergan. 2010. Effect of elevated circulating progesterone concentration on bovine blastocyst development and global transcriptome following endoscopic transfer of in vitro produced embryos to the bovine oviduct. Biol. Reprod. 83:707-719.

Carvalho, P. D., M. C. Wiltbank, and P. M. Fricke. 2015. Manipulation of progesterone to increase ovulatory response to the first $\mathrm{GnRH}$ treatment of an Ovsynch protocol in lactating dairy cows receiving first timed artificial insemination. J. Dairy Sci. 98:8800-8813.

Clemente, M., J. de La Fuente, T. Fair, A. Al Naib, A. Gutierrez-Adan, J. F. Roche, D. Rizos, and P. Lonergan. 2009. Progesterone and conceptus elongation in cattle: A direct effect on the embryo or an indirect effect via the endometrium? Reproduction 138:507-517.

Diaz, F. J., W. Luo, and M. C. Wiltbank. 2013. Prostaglandin F2alpha regulation of mRNA for activating protein 1 transcriptional factors in porcine corpora lutea (CL): Lack of induction of JUN and JUND in CL without luteolytic capacity. Domest. Anim. Endocrinol. 44:98-108.

Forde, N., M. E. Beltman, G. B. Duffy, P. Duffy, J. P. Mehta, P. O'Gaora, J. F. Roche, P. Lonergan, and M. A. Crowe. 2011. Changes in the endometrial transcriptome during the bovine estrous cycle: Effect of low circulating progesterone and consequences for conceptus elongation. Biol. Reprod. 84:266-278.

Forde, N., F. Carter, T. Fair, M. A. Crowe, A. C. O. Evans, T. E Spencer, F. W. Bazer, R. McBride, M. P. Boland, P. O'Gaora, P. Lonergan, and J. F. Roche. 2009. Progesterone-regulated changes in endometrial gene expression contribute to advanced conceptus development in cattle. Biol. Reprod. 81:784-794.

Forde, N., J. P. Mehta, M. Minten, M. A. Crowe, J. F. Roche, T. E. Spencer, and P. Lonergan. 2012. Effects of low progesterone on the endometrial transcriptome in cattle. Biol. Reprod. 87:124.

Fricke, P. M., P. D. Carvalho, M. C. Lucy, F. Curran, M. M. Herlihy, S. M. Waters, J. A. Larkin, M. A. Crowe, and S. T. Butler. 2016. Effect of manipulating progesterone before timed artificial insemination on reproductive and endocrine parameters in seasonal-calving pasture-based Holstein-Friesian cows. J. Dairy Sci. 99:6780-6792.

Gifford, C. A., K. Racicot, D. S. Clark, K. J. Austin, T. R. Hansen, M. C. Lucy, C. J. Davies, and T. L. Ott. 2007. Regulation of interferon-stimulated genes in peripheral blood leukocytes in pregnant and bred, nonpregnant dairy cows. J. Dairy Sci. 90:274-280.

Giordano, J. O., J. N. Guenther, G. Lopes, and P. M. Fricke. 2012. Changes in serum pregnancy-associated glycoprotein, pregnancy- 
specific protein $\mathrm{B}$, and progesterone concentrations before and after induction of pregnancy loss in lactating dairy cows. J. Dairy Sci. 95:683-697.

Gray, C. A., C. A. Abbey, P. D. Beremand, Y. Choi, J. L. Farmer, D. L. Adelson, T. L. Thomas, F. W. Bazer, and T. E. Spencer. 2006. Identification of endometrial genes regulated by early pregnancy, progesterone, and interferon tau in the ovine uterus. Biol. Reprod. 74:383-394.

Green, J. C., C. S. Okamura, S. E. Poock, and M. C. Lucy. 2010. Measurement of interferon-tau (IFN- $\tau$ ) stimulated gene expression in blood leukocytes for pregnancy diagnosis within 18-20 d after insemination in dairy cattle. Anim. Reprod. Sci. 121:24-33.

Gümen, A., J. N. Guenther, and M. C. Wiltbank. 2003. Follicular size and response to Ovsynch versus detection of estrus in anovulatory and ovular lactating dairy cows. J. Dairy Sci. 86:3184-3194.

Han, H., K. J. Austin, L. A. Rempel, and T. R. Hansen. 2006. Low blood ISG15 mRNA and progesterone levels are predictive of nonpregnant dairy cows. J. Endocrinol. 191:505-512.

Haugejorden, G., S. Waage, E. Dahl, K. Karlbert, J. F. Beckers, and E. Ropstad. 2006. Pregnancy associated glycoproteins (PAG) in postpartum cows, ewes, goats and their offspring. Theriogenology 66:1976-1984.

Henricks, D. M., J. T. Long, J. R. Hill, and J. F. Dickey. 1974. Effect of prostaglandin F2-apha during various stages of estrous cycle of beef heifers. J. Reprod. Fertil. 41:113-120.

Hughes, E. A., and D. A. Davies. 1989. Practical uses of ultrasound in early pregnancy in cattle. Vet. Rec. 124:456-458.

Kenyon, A. G., L. G. D. Mendonça, G. Lopes, J. R. Lima, J. E. P. Santos, and R. C. Chebel. 2013. Minimal progesterone concentration required for embryo survival after embryo transfer in lactating Holstein cows. Anim. Reprod. Sci. 136:223-230.

Kimmins, S., and L. A. Maclaren. 2001. Oestrous cycle and pregnancy effects on the distribution of oestrogen and progesterone receptors in bovine endometrium. Placenta 22:742-748.

Laporta, J., T. L. Peters, S. R. Weaver, K. E. Merriman, and L. L. Hernandez. 2013. Feeding 5-hydroxy-l-tryptophan during the transition from pregnancy to lactation increases calcium mobilization from bone in rats. Domest. Anim. Endocrinol. 44:176-184.

Lessey, B. A., A. O. Ilesanmi, A. J. Castelbaum, L. Yuan, S. G. Somkuti, P. G. Satyaswaroop, and K. Chwalisz. 1996. Characterization of the functional progesterone receptor in an endometrial adenocarcinoma cell line (Ishikawa): Progesterone-induced expression of the $\alpha 1$ integrin. J. Steroid Biochem. Mol. Biol. 59:31-39.

Livak, K. J., and T. D. Schmittgen. 2001. Analysis of relative gene expression data using real-time quantitative PCR and the $2-\Delta \Delta \mathrm{CT}$ method. Methods 25:402-408.

López-Gatius, F., J. M. Garbayo, P. Santolaria, J. Yániz, A. Ayad, N. M. d. Sousa, and J. F. Beckers. 2007. Milk production correlates negatively with plasma levels of pregnancy-associated glycoprotein (PAG) during the early fetal period in high producing dairy cows with live fetuses. Domest. Anim. Endocrinol. 32:29-42.

Mann, G. E., M. D. Fray, and G. E. Lamming. 2006. Effects of time of progesterone supplementation on embryo development and interferon- $\tau$ production in the cow. Vet. J. 171:500-503.

Mann, G. E., and G. E. Lamming. 2001. Relationship between maternal endocrine environment, early embryo development and inhibition of the luteolytic mechanism in cows. Reproduction 121:175180.

Matsuyama, S., T. Kojima, S. Kato, and K. Kimura. 2012. Relationship between quantity of IFNT estimated by IFN-stimulated gene expression in peripheral blood mononuclear cells and bovine embryonic mortality after AI or ET. Reprod. Biol. Endocrinol. 10:21.

McCracken, J. A., E. E. Custer, and J. C. Lamsa. 1999. Luteolysis: A neuroendocrine-mediated event. Physiol. Rev. 79:263-323.

Momont, H. W., and B. E. Seguin. 1984. Influence of day of estrous cycle on response to PGF2 alpha products: Implication for AI programs for dairy cattle. Pages 336-338 in 10th International Congress on Animal Reproduction and Artificial Insemination. Vol. III, University of Illinois at Urbana-Champaign.
Mondal, M., B. Schilling, J. Folger, J. P. Steibel, H. Buchnick, Y. Zalman, J. J. Ireland, R. Meidan, and G. W. Smith. 2011. Deciphering the luteal transcriptome: Potential mechanisms mediating stage-specific luteolytic response of the corpus luteum to prostaglandin F-2 alpha. Physiol. Genomics 43:447-456.

Monteiro, P. L. J., A. B. Nascimento, G. C. S. Pontes, G. O. Fernandes, L. F. Melo, M. C. Wiltbank, and R. Sartori. 2015. Progesterone supplementation after ovulation: Effects on corpus luteum function and on fertility of dairy cows subjected to AI or ET. Theriogenology 84:1215-1224.

Monteiro, P. L. J., E. S. Ribeiro, R. P. Maciel, A. L. G. Dias, E. Solé, F. S. Lima, R. S. Bisinotto, W. W. Thatcher, R. Sartori, and J. E. P. Santos. 2014. Effects of supplemental progesterone after artificial insemination on expression of interferon-stimulated genes and fertility in dairy cows. J. Dairy Sci. 97:4907-4921.

Nascimento, A. B., R. W. Bender, A. H. Souza, H. Ayres, R. R. Araujo, J. N. Guenther, R. Sartori, and M. C. Wiltbank. 2013. Effect of treatment with human chorionic gonadotropin on day 5 after timed artificial insemination on fertility of lactating dairy cows. J. Dairy Sci. 96:2873-2882.

Nascimento, A. B., A. H. Souza, A. Keskin, R. Sartori, and M. C. Wiltbank. 2014. Lack of complete regression of the Day 5 corpus luteum after one or two doses of $\mathrm{PGF}_{2 \alpha}$ in nonlactating Holstein cows. Theriogenology 81:389-395.

NRC. 2001. Nutrient Requirements of Dairy Cattle. 7th rev. ed. The National Academies Press, Washington, DC.

Parr, M. H., M. A. Crowe, P. Lonergan, A. C. O. Evans, D. Rizos, and M. G. Diskin. 2014. Effect of exogenous progesterone supplementation in the early luteal phase post-insemination on pregnancy per artificial insemination in Holstein-Friesian cows. Anim. Reprod. Sci. 150:7-14

Rexroad, C. E., L. E. Casida, and W. J. Tyler. 1974. Crown-rump length of fetuses in purebred Holstein-Frisian cows. J. Dairy Sci. $57: 346-347$.

Ricci, A., P. D. Carvalho, M. C. Amundson, R. H. Fourdraine, L. Vincenti, and P. M. Fricke. 2015. Factors associated with pregnancyassociated glycoprotein (PAG) levels in plasma and milk of Holstein cows during early pregnancy and their effect on the accuracy of pregnancy diagnosis. J. Dairy Sci. 98:2502-2514.

Roberts, R. M., L. Liu, and A. Alexenko. 1997. New and atypical families of type I interferons in mammals: Comparative functions, structures, and evolutionary relationships. Prog. Nucleic Acid Res. Mol. Biol. 56:287-325.

Rowson, L. E., R. Tervit, and A. Brand. 1972. The use of prostaglandins for synchronization of oestrus in cattle. J. Reprod. Fertil. $29: 145$.

Sangsritavong, S., D. K. Combs, R. Sartori, L. E. Armentano, and M. C. Wiltbank. 2002. High feed intake increases liver blood flow and metabolism of progesterone and estradiol- $17 \beta$ in dairy cattle. J. Dairy Sci. 85:2831-2842.

Sartori, R., J. M. Haughian, R. D. Shaver, G. J. M. Rosa, and M. C. Wiltbank. 2004. Comparison of ovarian function and circulating steroids in estrous cycles of Holstein heifers and lactating cows. J. Dairy Sci. 87:905-920.

Sasser, R. G., C. A. Ruder, K. A. Ivani, J. E. Butler, and W. C. Hamilton. 1986. Detection of pregnancy by radioimmunoassay of a novel pregnancy-specific protein in serum of cows and a profile of serum concentration during gestation. Biol. Reprod. 35:936-942.

Souza, A. H., H. Ayres, R. M. Ferreira, and M. C. Wiltbank. 2008. A new presynchronization system (Double-Ovsynch) increases fertility at first postpartum timed AI in lactating dairy cows. Theriogenology 70:208-215.

Spencer, T. E., and F. W. Bazer. 1995. Temporal and spatial alterations in uterine estrogen receptor and progesterone receptor gene expression during the estrous cycle and early pregnancy in the ewe. Biol. Reprod. 53:1527-1543.

Spencer, T. E., and F. W. Bazer. 2002. Biology of progesterone action during pregnancy recognition and maintenance of pregnancy. Front. Biosci. 7:d1879-d1898. 
Spencer, T. E., and F. W. Bazer. 2004. Conceptus signals for establishment and maintenance of pregnancy. Reprod. Biol. Endocrinol. 2:49-63.

Spencer, T. E., N. Forde, and P. Lonergan. 2016. The role of progesterone and conceptus-derived factors in uterine biology during early pregnancy in ruminants. J. Dairy Sci. 99:5941-5950.

Spencer, T. E., G. A. Johnson, F. W. Bazer, R. C. Burghardt, and M. Palmarini. 2007. Pregnancy recognition and conceptus implantation in domestic ruminants: Roles of progesterone, interferons and endogenous retroviruses. Reprod. Fertil. Dev. 19:65-78.

Sterry, R. A., E. Silva, D. Kolb, and P. M. Fricke. 2009. Strategic treatment of anovular dairy cows with GnRH. Theriogenology $71: 534-542$

Stevenson, J. S., M. A. Portaluppi, D. E. Tenhouse, A. Lloyd, D. R. Eborn, S. Kacuba, and J. M. DeJarnette. 2007. Interventions after artificial insemination: Conception rates, pregnancy survival, and ovarian responses to gonadotropin-releasing hormone, human chorionic gonadotropin, and progesterone. J. Dairy Sci. 90:331-340.

Tsai, S. J., and M. C. Wiltbank. 1998. Prostaglandin F2alpha regulates distinct physiological changes in early and mid-cycle bovine corpora lutea. Biol. Reprod. 58:346-352.

Vasconcelos, J. L. M., S. Sangsritavong, S. J. Tsai, and M. C. Wiltbank. 2003. Acute reduction in serum progesterone concentrations after feed intake in dairy cows. Theriogenology 60:795-807.

Wiltbank, M., H. Lopez, R. Sartori, S. Sangsritavong, and A. Gümen. 2006. Changes in reproductive physiology of lactating dairy cows due to elevated steroid metabolism. Theriogenology 65:17-29.

Yan, L., R. Robinson, Z. Shi, and G. Mann. 2016. Efficacy of progesterone supplementation during early pregnancy in cows: A metaanalysis. Theriogenology 85:1390-1398. 